\title{
Sodium Retrieval from Sap May Permit Maintenance of Carbohydrate Reserves in Mature Xylem Tissues of a Salt-tolerant Hybrid Pistachio Rootstock Exposed to $100 \mathrm{~mm} \mathbf{~ N a C l}$
}

\author{
Jessie M. Godfrey \\ U.S. Department of Agriculture, Forest Service, Moscow Forestry Sciences Laboratory, 1221 \\ South Main Street, Moscow, ID 83843 \\ Louise Ferguson and Maciej A. Zwieniecki \\ Department of Plant Sciences, University of California Davis, One Shields Avenue, Davis, CA \\ 95616
}

\begin{abstract}
AdDitional INDEX wORDs. nonstructural carbohydrates, Pistacia, tree crops, xylem retrieval
Abstract. Salinity's many stresses may not kill a relatively salt-tolerant perennial in one season, but they can still deplete or modify nonstructural carbohydrate (NSC) pools. Any change to the quantity or quality of NSC reserves may have detrimental effects on phenology and reproduction, as well as yield, in tree crops. This study integrates salinity's infringement on the energy margins of pistachio rootstock 'UCB-1' (an interspecific hybrid of Pistacia atlantica and $P$. integerrima) at senescence by measuring sugar and starch pools in wood, bark, and roots after treatment with $\approx 100$ days of moderate to high salinity $\left(50-100 \mathrm{~mm} \mathrm{NaCl}\right.$ and $\left.10-20 \mathrm{~mm} \mathrm{CaCl}_{2}\right)$. Supported by a second experiment using sodium orthovanadate $(\mathrm{NaOV})$ to block active xylem retrieval in the same hybrid pistachio rootstock, we conclude that retrieval of $\mathrm{Na}^{+}$from xylem sap may allow for the preservation of NSC pools (particularly, starch) in mature xylem tissues by limiting the demand for carbon-based osmoticum (sugars). In contrast, younger growing tissues (bark and fine roots) were found to counteract salinity by degrading carbon-dense starch into osmotically active sugars at the expense of total NSC reserves, suggesting a physiological shift toward protection/isolation from environmentally pervasive but potentially toxic salts in these tissues.
\end{abstract}

The energetic costs of salinity tolerance in crop plants have led discussions in the literature for decades (Munns and Gilliham, 2015; Raven, 1985; Yeo, 1983). Recently, many of the world's top salinity experts contributed to joint papers recognizing the issue or articulating its complexity (Munns et al., 2020a, 2020b; Tyerman et al., 2019). A salt-tolerant crop must not only minimize salinity's negative effects on leaf and canopy growth (Perica et al., 2008; Rahneshan et al., 2018; Vijayan, 2009; Walker et al., 1988), leaf longevity (Arbona et al., 2005; Ferguson et al., 2002; Hassine and Lutts, 2010; Hoffman et al., 1989), and photosynthetic activity (Downton et al., 1990; Percival, 2005), but also maintain yields above some economically viable threshold. This is a

Received for publication 24 Nov. 2020. Accepted for publication 18 Feb. 2021.

Published online 5 May 2021

Funding for the bulk of this work was provided by the California Pistachio Research Board, the Henry Jastro Graduate Research Award, and the University of California, Davis (UC Davis) Horticulture and Agronomy Graduate Group. We thank Pioneer Nursery for their sapling donations. Revisions of the manuscript were supported by the U.S. Department of Agriculture (USDA) Forest Service, Rocky Mountain Research Station.

The findings and conclusions in this publication are those of the authors and should not be construed to represent any official USDA or U.S. government determination or policy.

We thank UC Davis professors Matthew Gilbert and Stephen R. Grattan for their input on the manuscript.

J.M.G. is the corresponding author. E-mail: jessie.godfrey@usda.gov.

This is an open access article distributed under the CC BY-NC-ND license (https://creativecommons.org/licenses/by-nc-nd/4.0/). difficult charge for most crops, given the mentioned limits to energy supply as well as the energy consumption required to synthesize compatible solutes (García-Caparrós et al., 2016; Slama et al., 2008) or to move salts actively across membranes (Malagoli et al., 2008). These are tasks fundamental to many broader salinity tolerance mechanisms, representing permanent extra diversions of carbon that otherwise might be directed to growth or reproduction.

Particularly for tree crops, which are slow to reach maturity and/or reliant on one season's carbon accumulation for the next season's success (Furze et al., 2019; Tixier et al., 2019), it may be useful to predict salinity's impacts on yield by measuring salinity's impacts on NSCs. Plant NSC status (much like plant water status) has great potential to inform our understanding of the degree to which a stress is encroaching on a tree's safety margin (McDowell, 2011; Sala et al., 2010). Furthermore, well before NSC depletion, any uncharacteristic changes to the dynamics of a tree's NSC pools may indicate future negative effects on phenology and reproduction (Sperling et al., 2019; Tixier et al., 2017). That said, although integrating the effects of salinity on a plant's overall health through its total NSC status is a promising tool for orchard managers, it should not be used as a stand-alone metric. Although some depletion of energy reserves is expected if salinity's impacts are prolonged or severe, moderate levels of applied stress may not necessarily lead to declines in total stored NSCs, particularly not in the short term. Even if stress leads to lower quantities of incoming carbohydrates or higher rates of stress-related carbohydrate use, stress may also weaken growth 
(or reproduction) as a carbohydrate sink, mitigating impacts on reserves (Kozlowski and Pallardy, 2002). Furthermore, regardless of whether declines in a tree's total NSC pools are observed, salinity introduces other potential questions related to NSCs. A large percentage of a tree's NSC pool is stored in xylem parenchyma (Schiestl-Aalto et al., 2019), and these living cells are involved in the lateral transport of ions out of (or into) xylem conduits (Aubry et al., 2019; van Bel, 1990). Are there tradeoffs between salt storage in the xylem and NSC storage?

Retrieval of $\mathrm{Na}^{+}$from xylem conduits and storage in xylem parenchyma may slow irreversible $\mathrm{Na}+$ accumulation in leaves and so extend the length of a saline growing season. This has been investigated primarily in the roots of Arabidopsis thaliana for application primarily in the breeding of salt-tolerant shortlived cereals [reviewed in Horie et al. (2009) and Munns et al. (2006)]. However, Godfrey et al. (2019) recently reported the same phenomenon in stems of Pistacia, the genus of Mediterranean woody perennials used in our study for its relative salinity tolerance (Ferguson et al., 2005; Grieve et al., 2012; Marino et al., 2019). Cations such as $\mathrm{Na}^{+}$tend to leak passively through membrane channels from the apoplast into the symplast, but they may also be pumped actively (Amtmann and Beilby, 2010). Like any other process involving passage across membranes, if xylem retrieval is active, it is inevitably carbon costly, and dependent on the presence and use of adenosine triphosphate (ATP) (Sun et al., 2009). It is important to test whether salt retrieval in trees is indeed an active process. If so, this might represent a long-term drain on NSC reserves. Perhaps more importantly, xylem retrieval of salt by parenchymal cells may physically limit the accumulation of NSCs. Storing $\mathrm{Na}^{+}$in the vacuoles of xylem parenchyma potentially reduces the cytoplasmic space allocated to starch storage (amyloplasts) and carbonbased osmoticum (sugars), and suggests hypothetically a tradeoff between NSC storage and salt concentration. In addition, as $\mathrm{Na}^{+}$ retrieval occurs along the length of a tree's stem, its impacts to NSCs may depend on location along the stem, as well as on the concentration and/or duration of salinity exposure.

We present results from two experiments. In a container experiment with hybrid pistachio rootstock 'UCB-1' (an interspecific hybrid of Pistacia atlantica and P. integerrima), we tested the hypothesis that salinity levels and tissue type affect NSC responses differentially to salinity stress. We report physiological changes over the course of one season of $\mathrm{NaCl}$ treatments as well as NSC concentrations at several points along the transpiration stream at senescence. In addition, to test the hypothesis that some xylem retrieval is active, we used branch segments from mature trees of the same Pistacia cultivar as well as a peristaltic pump and $\mathrm{NaOV}$, a known blocker of the hydrogen ATPase proton pumps that facilitate $\mathrm{Na}^{+}$transport across membranes (Sun et al., 2009). Our objectives were to interfere with active xylem retrieval and observe the effects on long-distance $\mathrm{Na}^{+}$transport through the xylem.

\section{Methods}

\section{Expt. 1}

Plant material and growing conditions. Early in Spring 2015, 39 clonally propagated 1-year-old 'UCB-1' hybrid pistachio rootstocks were removed from their nursery pots, washed of any medium, and transplanted into perforated 11-L pots lined with a doubled nylon mesh and filled with coarse sand. Pots were placed above trays filled with washed pea gravel and connected into a gravity-driven effluent recapture and redistribution system on raised beds outdoors at a University of California, Davis (UC Davis) facility (lat. $38.542^{\circ} \mathrm{N}$, long. $121.762^{\circ} \mathrm{W}$ ). Daily irrigation at $1600 \mathrm{HR}$ with a modified half-Hoagland's solution began immediately. When leaves from the first flush were fully expanded and an initial sampling of three seedlings on day of the year (DOY) 175 was conducted, daily irrigation at $1600 \mathrm{HR}$ switched (DOY 204) to 12 replicate treatments of control (modified Hoagland's solution $+0 \mathrm{~mm} \mathrm{NaCl}$ ), moderate salinity (modified Hoagland's solution $+50 \mathrm{~mm} \mathrm{NaCl}+10 \mathrm{~mm} \mathrm{CaCl}_{2}$ ), or high salinity (modified Hoagland's solution $+100 \mathrm{~mm} \mathrm{NaCl}+20 \mathrm{~mm}$ $\mathrm{CaCl}_{2}$ ). In a very similar setup conducted over a shorter time period, the same high-salinity irrigation treatment caused declines in physiological metrics, but did not overwhelm the 'UCB-1' rootstock's capacity for xylem retrieval (Godfrey et al., 2019). In addition, work on mature trees suggests that $10 \mathrm{dS} \cdot \mathrm{m}^{-1}$ (roughly equivalent to our 100-mm treatment in terms of conductivity, although the composition of the irrigation water was different) appears to be the inflection point for yield on Pistacia vera budded to 'UCB-1' (Sanden et al., 2004). Each irrigation flushed pots beyond soil water holding capacity such that the soil solution was replaced daily, with at least one-third of the applied irrigation leaking from perforations at the bottom of each pot. Pots were arranged across five rows per treatment (two or three pots per row, interspersed to limit shadowing). To avoid osmotic shock, we increased the concentration of our highest salinity treatment in two daily steps of $50 \mathrm{~mm} \mathrm{NaCl}+10 \mathrm{~mm} \mathrm{CaCl}_{2}$ starting on DOY 202 .

As mentioned, three trees were selected at random 1 month before the start of salinity treatments (DOY 175 of year 1). Four trees from each treatment were selected randomly after 10 weeks of salinity treatments, followed by senescence in November (DOY 319-325 of year 1). A sampling after leaf-out during the second year was canceled because six trees died over the course of the following winter (two in the moderate-salinity treatment and four in the high-salinity treatment). After the dormant season, a full growing season of recovery from salinity treatments, and a second round of senescence (DOY 324-328 of year 2), the remaining trees were again sampled destructively and three trees from each treatment were selected at random for NSC analysis.

IN VIVo MEASUREMENTS. The trunk diameters and canopy areas of all 12 trees in each treatment were measured every 2 weeks in the first season. Trunk diameter was measured always at the same marked position, $20 \mathrm{~cm}$ up from the soil. Photos of saplings were taken early in the morning, before shadows were cast, against a white posterboard background and were then processed using ImageJ software (version 1.51g; U.S. National Institutes of Health, Bethesda, MD) (Schneider et al., 2012) to assess changes to canopy area over time.

Also, at an $\approx 2$-week interval, five trees from each treatment (one per row) were selected randomly for measurements of photosynthesis $\left(A_{\mathrm{n}}\right)$, stomatal conductance $\left(g_{\mathrm{S}}\right)$, intercellular $\mathrm{CO}_{2}$ concentration $\left(C_{\mathrm{i}}\right)$, the pressure required to balance stem water potential at midday, and evapotranspiration. Gas exchange measurements were taken using a round $1.5-\mathrm{cm}$-diameter chamber attached to a portable photosynthesis system (LI-6400; LI-COR, Lincoln, NE) between 0900 and 1030 HR (morning) and again between 1500 and $1600 \mathrm{HR}$ (afternoon). The flow rate was set to $500 \mu \mathrm{mol} \cdot \mathrm{s}^{-1}$, the reference $\mathrm{CO}_{2}$ concentration was set to 400 $\mu \mathrm{mol} \cdot \mathrm{mol}^{-1}$, and photosynthetically active radiation was set to $1500 \mu \mathrm{mol} \cdot \mathrm{m}^{-2} \cdot \mathrm{s}^{-1}$ light-saturating photon flux density. For 
midday water potential measurements, one leaf from each tree was sealed in a moist reflective (light-tight) bag to equilibrate for 10 to $15 \mathrm{~min}$ in the field before excision with a razor at $1200 \mathrm{HR}$. Allowing time for transport to the laboratory and the measurements of other samples, $\approx 20$ to 120 min elapsed between leaf excision and pressure chamber measurements (Scholander et al., 1965). The evapotranspiration rate of each pot was measured using a balance, dividing the difference in measured afternoon $(\approx 1500 \mathrm{HR})$ and morning $(\approx 0900 \mathrm{HR})$ weights by the time between measurements.

Destructive Sampling AND NSC analysis. Trees were removed from pots and their roots washed of sand in the field at $\approx 0900 \mathrm{HR}$. After transport back to the laboratory, all stem samples collected for NSC analysis were separated immediately from bark and dried at $\approx 80^{\circ} \mathrm{C}$ for $48 \mathrm{~h}$; root samples were rinsed with deionized water before drying. Samples were then homogenized using a minibead beater (Biospec Products, Bartlesville, OK) and analyzed using hydrolytic enzyme reactions coupled with a sulfuric acid-anthrone assay in a method modified from Leyva et al. (2008). Modifications are described by Tixier et al. (2018).

Statistical analysis. NSCs were compared after salinity treatments as well as after recovery from salinity treatments using a combination of analysis of variance (ANOVA) and Tukey's honestly significant difference (HSD) test at $P<0.05$. Linear mixed-effects models using individual tree as a random effect were fit to repeated measurements of growth and either morning or afternoon $A_{\mathrm{n}}$, and were compared using ANOVA. Comparisons of either morning or afternoon $A_{\mathrm{n}}$ at a single point in time were made among treatments using a combination of ANOVA and Tukey's HSD test $(P<0.05)$. All measurements of $A_{\mathrm{n}}$ were compared with all measurements of $g_{\mathrm{S}}$ or all measurements of $C_{\mathrm{i}}$ using linear mixed-effects models with individual tree as a random effect. Separations among treatments were made for each physiological measurement using a combination of ANOVA and Tukey's HSD test $(P<0.05)$ with type II sums of squares.

\section{Expt. 2}

Peristaltic Pump. Late in Spring 2015, 2- to 3-year-old unbranched stem segments $\approx 10 \mathrm{~mm}$ thick and $10 \mathrm{~cm}$ long were separated from never-budded, mature ( $>10$ years old) 'UCB-1' hybrid pistachio rootstocks growing in soil at a UC Davis field site (lat. $38.542^{\circ} \mathrm{N}$, long. $121.795^{\circ} \mathrm{W}$ ) and transported to the laboratory in a sealed plastic bag. When in the laboratory, $1 \mathrm{~cm}$ was cut under water from the proximal and distal ends of each segment, the bark was removed from the proximal end, and the proximal xylem diameter was measured to estimate a stem-specific transpiration (perfusion) rate. Calculations assumed a moderate leaf transpiration rate of $3 \mathrm{mmol} \cdot \mathrm{m}^{-2} \cdot \mathrm{s}^{-1}$ and, similar to seedlings at the start of Expt. 1 (a total leaf area of $500 \mathrm{~cm}^{2}$ ) for a branch $10 \mathrm{~mm}$ in diameter (or with a cross-sectional area of $\approx 78 \mathrm{~mm}^{2}$ ), such that the total transpiration of the described branch would be $\approx 10 \mathrm{~mL} \cdot \mathrm{h}^{-1}$. These values were then used as inputs so that the estimated transpiration (perfusion) rate for a stem segment with a proximal end area $A_{\text {stem }}$ would be $10 \mathrm{~mL} \cdot \mathrm{h}^{-1} \times$ $A_{\text {stem }} \times 78 \mathrm{~mm}^{-2}$. The proximal end of each segment was then connected to a calibrated peristaltic pump (REGLO; Ismatec, Wertheim, Germany), and room-temperature $\left(\approx 22^{\circ} \mathrm{C}\right)$ solutions of either $100 \mathrm{mg} \cdot \mathrm{L}^{-1} \mathrm{NaCl}\left(\approx 4.35 \mathrm{mM} \mathrm{Na}{ }^{+}\right)$or $100 \mathrm{mg} \cdot \mathrm{L}^{-1}$ $\mathrm{NaCl}$ combined with $0.5 \mathrm{~mm} \mathrm{NaOV}\left(\approx 4.85 \mathrm{mM} \mathrm{Na}^{+}\right)$were perfused through stems at the calculated rate. A total of $100 \mathrm{mg} \cdot \mathrm{L}^{-1}$
$\mathrm{NaCl}$ was selected to approximate the concentrations of $\mathrm{Na}^{+}$ likely to be found in stems treated, but not overwhelmed, by salinity treatments (Godfrey et al., 2019); $0.5 \mathrm{~mm} \mathrm{NaOV}$ was selected to interfere with plasma membrane $\mathrm{Na}^{+}$transport (Sun et al., 2009). Cumulative outflow was collected at $\approx 2-\mathrm{h}$ intervals into a $15-\mathrm{mL}$ Eppendorf tube from the distal end of each stem for a total of six times over the course of $12 \mathrm{~h}$. For this first round of simultaneous measurements, two stems were perfused with the $\mathrm{NaCl}$ solution and three stems were perfused with the $\mathrm{NaCl}+$ $\mathrm{NaOV}$ solutions. The following day, three additional stems were perfused for $24 \mathrm{~h}$ with the $\mathrm{NaCl}$ solution, and outflow was again collected six times over that period, but this time at intervals of $\approx 4 \mathrm{~h}$ in 50 -mL Eppendorf tubes.

Sodium ANALysis. The volumes of aqueous samples collected from the cut distal ends of perfused stems were determined by extracting these volumes from outflow containers with a pipette. Samples were then diluted to accommodate a sodium-specific electrode $\approx 1 \mathrm{~cm}$ in diameter (Orion Sodium Electrode; Thermo Fisher Scientific, Waltham, MA). Values measured in millivolts were converted to millimolar using a sodium standard calibration curve.

Statistical AnAlysis. A linear model (second-order polynomial) was fit to all measurements of the volumes and $\mathrm{Na}^{+}$concentrations exiting stems for each of the two perfusion solutions ( $\mathrm{NaCl}$ only and $\mathrm{NaCl}$ combined with $\mathrm{NaOV}$ ). The generated models were then compared using ANOVA.

\section{Results}

RESERVES OF NSC SIGNIFICANTLY LESS IN YOUNG TISSUES SAMPLED AT SENESCENCE. Reserves of starch, soluble sugar, or their combination (total NSCs) heading into dormancy after one season of salinity treatments were affected only in young/growing tissues (Table 1, Fig. 1). In distal (current-year) wood (Fig. 1A), midstem bark (Fig. 1D), and fine roots (Fig. 1H), significantly lower starch concentrations $(P=0.04, P<0.01$, and $P=0.04$, respectively) resulted in significantly lower total NSC reserves ( $P=0.03, P=0.02$, and $P=0.05$, respectively). In distal bark (Fig. 1B) and proximal bark (Fig. 1F), significant decreases in starch concentration ( $P=0.02$ and $P=0.02$, respectively) were matched by significant increases in sugar concentration $(P<$ 0.05 and $P<0.01$, respectively), such that we observed no significant impact on total NSCs within these tissues. In more mature tissues such as midstem wood (Fig. 1C), proximal wood (Fig. 1E), and coarse roots (Fig. 1G), no carbohydrate form was affected significantly by salinity treatments. Interestingly, if saplings survived through dormancy and spring leaf-out, one season of nonsaline irrigation water (control treatment) was enough to make pools of all carbohydrate forms in all tissues indistinguishable statistically from those of saplings in the control $(P>0.10$; data not shown).

Significant INTERACTIVE EFFECTS OF SALINITY TREATMENT AND TIME FOR BOTH CANOPY AND STEM GROWTH METRICS. Treatment $(P<0.01)$ and the interaction between treatment and time $(P<0.01)$, but not time alone $(P=0.76)$, affected repeated measures of canopy area significantly (Fig. 2A). No significant differences in canopy size were observed between trees assigned to treatments before treatment on DOY $203(P=0.80)$. After the start of treatment, salinity resulted in sustained decreases to canopy area (early senescence) during the course of the season; saplings demonstrated smaller canopies relative to the control 
Table 1. Summary statistics of an analysis of variance comparing starch, sugar, or total nonstructural carbohydrate (Total) concentrations in tissues of Pistacia atlantica $\times$ P. integerrima 'UCB-1' after $\approx 100 \mathrm{~d}$ of control [(C); modified Hoagland's solution $+0 \mathrm{~mm}$ NaCl], moderate-salinity $\left(\mathrm{C}+50 \mathrm{~mm} \mathrm{NaCl}+10 \mathrm{mM} \mathrm{CaCl}_{2}\right)$, or high-salinity $\left(\mathrm{C}+100 \mathrm{~mm} \mathrm{NaCl}+20 \mathrm{~mm} \mathrm{CaCl}_{2}\right)$ treatments.

\begin{tabular}{|c|c|c|c|c|c|c|}
\hline & \multicolumn{2}{|c|}{ Starch } & \multicolumn{2}{|c|}{ Sugar } & \multicolumn{2}{|c|}{ Total } \\
\hline & $P$ value & Significance & $P$ value & Significance & $P$ value & Significance \\
\hline Immature bark & 0.02 & $*$ & 0.05 & $*$ & 0.70 & NS \\
\hline Mature bark & $<0.01$ & $* *$ & $<0.01$ & $* *$ & 0.02 & $*$ \\
\hline Mature wood & 0.95 & NS & 0.36 & NS & 0.57 & NS \\
\hline Root crown bark & 0.02 & $*$ & $<0.01$ & $* *$ & 0.16 & NS \\
\hline Fine roots & 0.04 & $*$ & 0.11 & NS & 0.05 & $*$ \\
\hline
\end{tabular}

Ns, ***Nonsignificant or significant at $P<0.05$ or 0.01 , respectively.
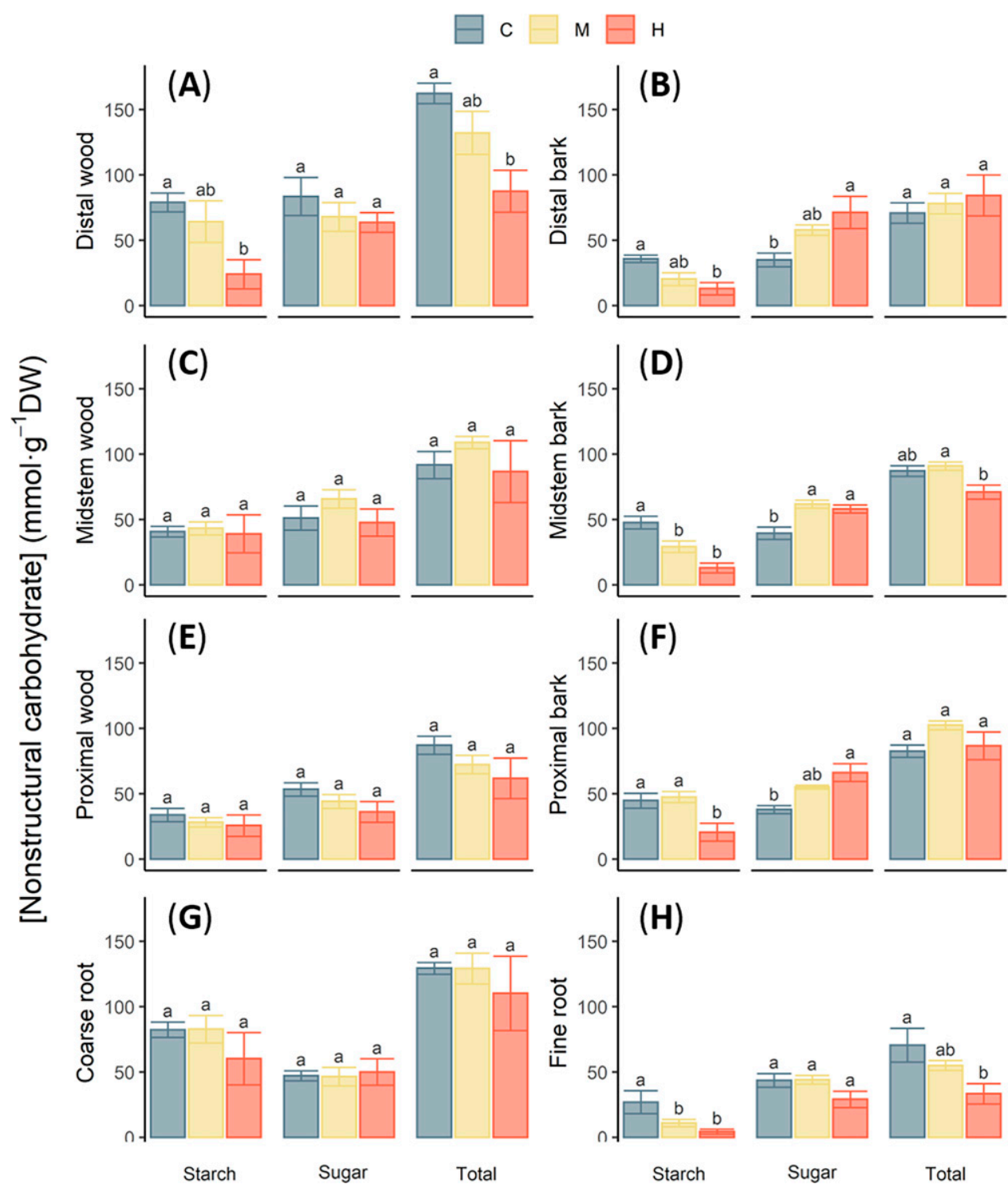

Fig. 1. November starch, sugar, or total nonstructural carbohydrate concentrations in the (A) immature wood, (B) immature bark, $(\mathbf{C})$ mature wood, $(\mathbf{D})$ mature bark, $(\mathbf{E})$ root crown wood, $(\mathbf{F})$ root crown bark, $(\mathbf{G})$ coarse roots, and (H) fine roots of Pistacia atlantica $\times$ P. integerrima 'UCB-1' after $\approx 100 \mathrm{~d}$ of control [(C) modified Hoagland's solution $+0 \mathrm{~mm} \mathrm{NaCl}$ ], moderate-salinity $\left[(\mathrm{M}) \mathrm{C}+50 \mathrm{~mm} \mathrm{NaCl}+10 \mathrm{~mm} \mathrm{CaCl}_{2}\right]$, or high-salinity $[(\mathrm{H}) \mathrm{C}+100 \mathrm{~mm}$ $\left.\mathrm{NaCl}+20 \mathrm{~mm} \mathrm{CaCl}_{2}\right]$ treatments. For any given panel, letters indicate significant differences within a given nonstructural carbohydrate form (Tukey's honestly significant difference at $P<0.05$ ). from the first measurement after treatment began (DOY 217) to the last (DOY 273). Significant differences between control and moderate-salinity treatments did not appear until the last measurement.

Time $(P<0.01)$ and the interaction between treatment and time $(P<0.01)$, but not treatment alone $(P=0.17)$, affected repeated measures of stem diameter significantly (Fig. 2B). No significant differences in stem diameter were observed among trees assigned to treatments before treatment on DOY 203 ( $P=$ 0.74). Significant differences between the stems of saplings growing in control and highsalinity treatments appeared after $\approx 6$ weeks of treatment (DOY 245) and continued through the last measurement (DOY 273). Stem diameter in the moderate treatment increased more slowly than the control, but comparisons at any single point in time demonstrated no significant differences.

IMPACTS ON $\boldsymbol{A}_{\mathrm{N}}$ AND PRESSURE REQUIRED TO BALANCE MIDDAY STEM TENSION, AND TRANSPIRATION. Repeated measures of both morning and afternoon $A_{\mathrm{n}}$ (Fig. $3 \mathrm{~A}$ and $\mathrm{B}$ ) demonstrated significant effects of treatment and time in treatment $(P<0.01)$, but not their interaction $(P=0.63$ and $P$ $=0.15$ for morning and afternoon measurements, respectively). No significant differences among trees assigned to treatments were 


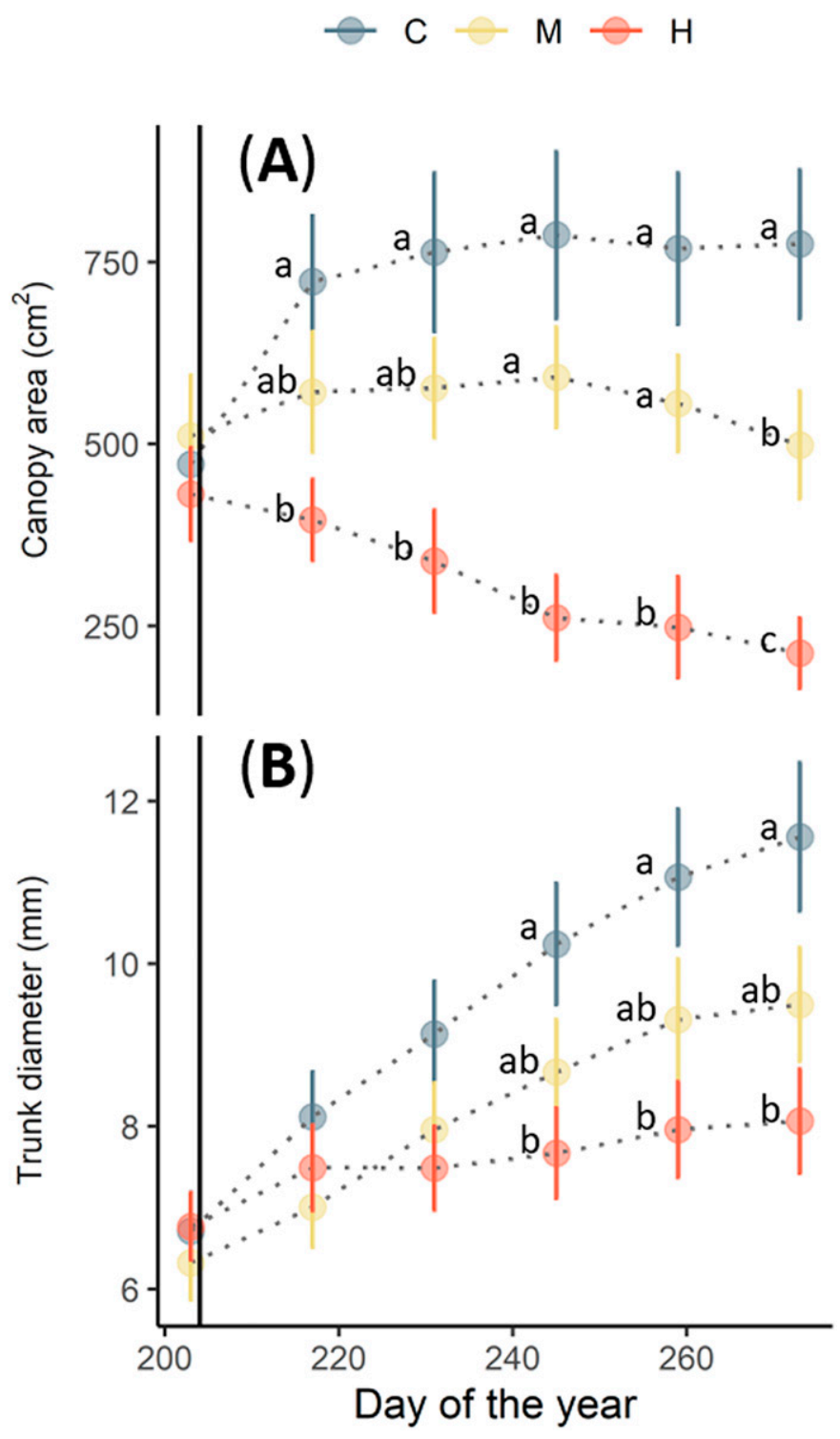

Fig. 2. Growth and senescence measured as (A) canopy area as well as (B) stem diameter for Pistacia atlantica $\times P$. integerrima 'UCB-1' after $\approx 100 \mathrm{~d}$ of control [(C) modified Hoagland's solution $+0 \mathrm{~mm} \mathrm{NaCl}$ ], moderate-salinity $\left[(\mathrm{M}) \mathrm{C}+50 \mathrm{~mm} \mathrm{NaCl}+10 \mathrm{~mm} \mathrm{CaCl}_{2}\right.$, or high-salinity $\left[(\mathrm{H}) \mathrm{C}+100 \mathrm{~mm} \mathrm{NaCl}+20 \mathrm{~mm} \mathrm{CaCl}_{2}\right]$ treatments. For any given panel, letters indicate significant differences within a given nonstructural carbohydrate form (Tukey's honestly significant difference at $P<0.05$ ). Bold, black vertical lines indicate the approximate start of treatment (less 1 or $2 \mathrm{~d}$ for medium- or high-salinity treatments, respectively).

observed before treatment on DOY $195(P=0.91$ and $P=0.98$ for morning and afternoon measurements, respectively). The high-salinity treatment demonstrated morning $A_{\mathrm{n}}$ values significantly less than control values in both early (DOY 216 and 227) and late (DOY 258 and 278) treatments, but these differences were absent for one intermediary measurement on DOY 244. Significantly less afternoon measurements were observed in both salinity treatments relative to the control early during treatment (DOY 216), but these effects extended later during treatment only for the high-salinity treatment.

Repeated measures of the pressure required to balance midday tension in the stem (Fig. 3C) demonstrated significant effects of treatment $(P<0.01)$, but not time $(P=$
$0.14)$ or the interaction between treatment and time $(P=$ $0.65)$. No significant differences were observed before treatment on DOY $202(P=0.89)$. Relative to the control, significantly greater pressures (i.e., more negative water potentials) were required to balance the high-salinity treatment early during treatment (DOY 216, 321, and 244), as well as the moderate-salinity treatment later on (DOY 244). However, differences were no longer significant for either treatment on the last sampling day (DOY 258).

Repeated-measures ANOVA of pot evapotranspiration (Fig. 3D) demonstrated significant effects of treatment $(P<0.01)$ and time $(P<0.01)$, as did the interaction between treatment and time $(P<0.05)$. No significant differences were observed before treatment on DOY $204(P=0.46)$. Significant differences between the control (higher) and high-salinity treatment (lower) were observed from the first evapotranspiration measurement after treatment began (DOY 216: $P<0.01$ ) to the last (DOY 272: $P<0.01)$.

DeClines in $\boldsymbol{A}_{\mathrm{N}}$ FOllow declines in $\boldsymbol{G}_{\mathrm{s}}$. Combining all gas exchange measurements (both times of day and all days of the year), $A_{\mathrm{n}}$ decreased with $g_{\mathrm{S}}$ (Fig. 4A). $A_{\mathrm{n}}$ was significantly less than the control when measured in trees exposed to both moderate- and high-salinity treatments (Tukey's HSD at $P<0.05$ ), whereas $g_{\mathrm{S}}$ was only significantly less than the control when measured in trees exposed to the high-salinity treatment (Tukey's HSD at $P<$ $0.05) . A_{\mathrm{n}}$ also increased significantly $(P<0.01)$ across treatments with $C_{\mathrm{i}}$ (Fig. 4B), but $C_{\mathrm{i}}$ was not significantly different among treatments $(P=0.14)$.

Xylem Retrieval of SODIUM IS ACtive. Linear models using branch segment as a random effect compared the cumulative volumes of $\mathrm{Na}^{+}$solution perfused through the stems of hybrid pistachio rootstock 'UCB-1' with the concentrations of $\mathrm{Na}^{+}$remaining in solution after perfusion. Significant differences $(P$ $<0.01)$ were observed as a result of the volume perfused as well as the perfusion solution (Fig. 5). Over $12 \mathrm{~h}$ of perfusion with a solution including only $\mathrm{NaCl}$, the initial sodium concentration of solution $\left(4.35 \mathrm{mM} \mathrm{Na}^{+}\right)$was never reached in the solution exiting stems. Over $12 \mathrm{~h}$ of perfusion with a solution including both $\mathrm{NaCl}$ and $\mathrm{NaOV}$, an ATPase inhibitor, the initial concentration of solution $\left(\approx 4.85 \mathrm{mM} \mathrm{Na}^{+}\right)$was reached quickly in the solution exiting stems. The explanatory power of both models was high, with $R_{\text {adj }}^{2}=0.742$ for the $\mathrm{NaCl}$ only solution and $R_{\text {adj }}^{2}=0.774$ for the solution including both $\mathrm{NaCl}$ and $\mathrm{NaOV}$.

\section{Discussion}

Although sugar concentrations were either maintained or increased relative to those of the control in all the hybrid pistachio rootstock 'UCB-1' tissues measured in our study after one season of high salinity, increases were at the expense of storage and were only observed in immature tissues (Fig. 1). Despite significantly less canopy and stem growth in our high-salinity treatment (Fig. 2), starch, the osmotically inactive but denser carbon form of NSCs, decreased in immature tissues. In many cases, decreases in starch were accompanied by decreases in total NSCs. In contrast, the lack of significantly different starch or total NSC concentrations in the moderate treatment suggests that declines in $A_{\mathrm{n}}$ under the moderate-salinity treatment (Fig. 3A and B) were matched effectively by carbon-equivalent declines in growth (Fig. 2). These findings lend evidence to the idea that sugar homeostasis, or at least some minimum sugar concentration, is fixed 


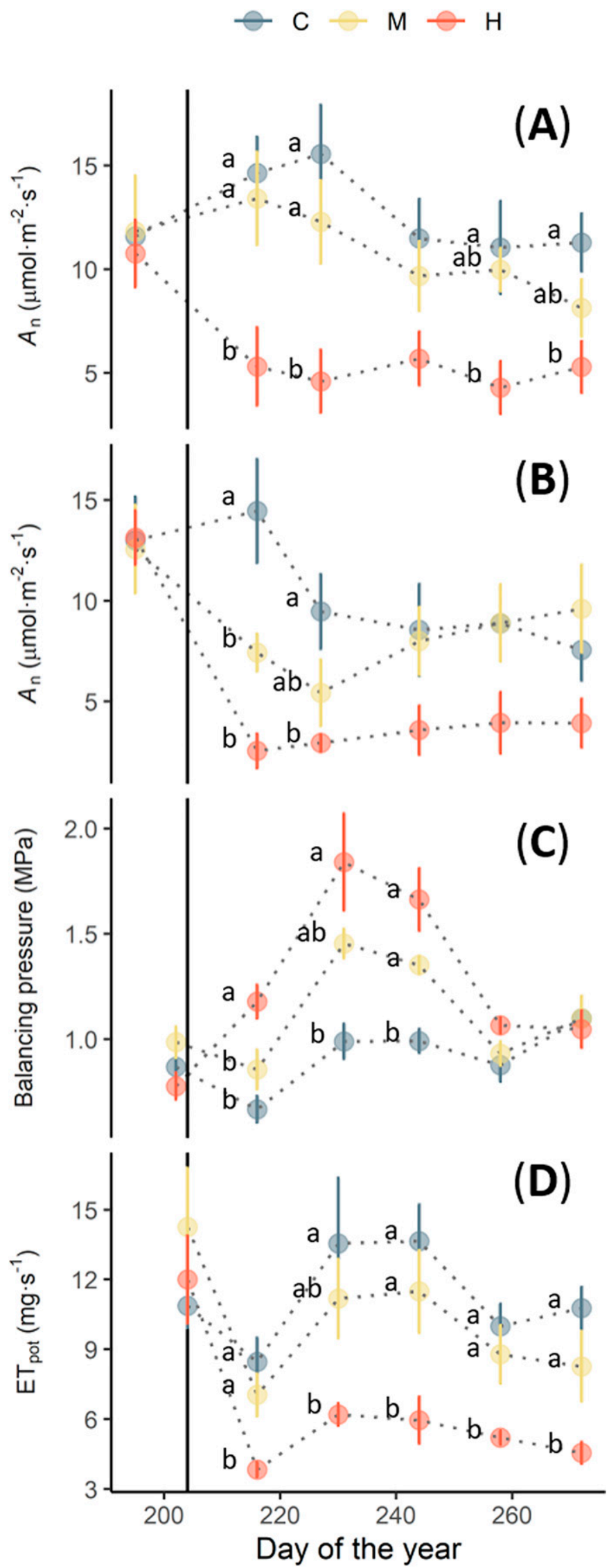

Fig. 3. Measurements of (A) morning and (B) afternoon photosynthesis $\left(A_{\mathrm{n}}\right)$ as well as $(\mathbf{C})$ the pressures required to balance midday xylem tension to maintain the life or functions of any tissue or cell (Granot et al., 2013; Rook et al., 2006). However, these findings also indicate eventual consequences for any tissue in which sugar is overexploited to achieve osmotic adjustment.

When salinity is high, tension in the xylem is often high (Fig. 3C), and tension must be managed or xylem vessels will embolize. One way that plants respond to tension under salinity is by closing stomata or otherwise limiting the demands of transpiration by limiting canopy growth. Another, often parallel route many plant species take is to adjust to the soil solution available osmotically. By either taking up salts from solution or converting starches to sugars and compatible solutes, relieving and/or meeting tension, osmotic adjustment serves to accommodate low water potentials in both the soil and, as needed, in the apoplast. The studied pistachios appear to respond to salinity using all the strategies mentioned; however, this response changes throughout the course of exposure to salinity and by tissue.

Specifically, although stem water potentials responded dramatically to both moderate and high salinity early in the season, by late in the season the water potentials of both salinity treatments were comparable to those of the control. This introduces interesting questions about the similarities between Pistacia and one of the world's most famous salinity-tolerant genera, Avicennia. Although pistachios do not secrete salts from their leaves, the uptake of some salts into the xylem sap may help them maintain hydraulic conductivity in a way comparable to this mangrove (Drennan and Pammenter, 1982; Scholander et al., 1962). We are curious about whether pistachios form hydrogels or mucilage in the inner walls of their xylem vessels (Zimmerman et al., 2002; Zwieniecki et al., 2001). Regardless, some $A_{\mathrm{n}}$ was maintained in this particular pistachio hybrid throughout the course of the season for both the moderate- and high-salinity treatments (Fig. 3), with $g_{\mathrm{S}}$ limited only minimally under moderate salinity (Fig. 4).

However, instead of using the most pervasive osmoticum in their environment to achieve osmotic adjustment, young tissues appear to preserve new cells from salt using sugars, effectively isolating them from the apoplastic environment. When salinity is high (and prolonged), this leads to a starch deficit relative to control trees heading into winter. In contrast with young tissues, neither moderate nor high salinity significantly reduced or increased the starch, sugar, or total NSC concentrations of mature (xylem-based) tissues measured at leaf senescence (Fig. 1). Constant concentrations of all forms of NSC from the xylem in coarse roots to the xylem in mature wood suggests that some inorganic osmoticum is used to achieve osmotic adjustment in all but the growing xylem. This osmoticum is likely $\mathrm{Na}^{+}$, given the source of salinity treatments and the observations of this study (Fig. 5) and previous studies (Godfrey et al., 2019). The possibility of using salts for osmotic adjustment is unique to salinity stress, and perhaps explains why starch concentrations are often maintained or even increased with salinity, but not with other abiotic stresses such as drought or heat (Thalmann and Santelia, 2017). In contrast to our initial

Fig. 3. (Continued). (balancing pressure) and (D) the per-pot evapotranspiration $\left(\mathrm{ET}_{\mathrm{pot}}\right)$ of Pistacia atlantica $\times P$. integerrima 'UCB-1' after $\approx 100 \mathrm{~d}$ of control [(C) modified Hoagland's solution $+0 \mathrm{~mm} \mathrm{NaCl}]$, moderate-salinity $\left[(\mathrm{M}) \mathrm{C}+50 \mathrm{~mm} \mathrm{NaCl}+10 \mathrm{mM} \mathrm{CaCl}_{2}\right]$, or high-salinity $[(\mathrm{H}) \mathrm{C}+$ $100 \mathrm{~mm} \mathrm{NaCl}+20 \mathrm{mM} \mathrm{CaCl}_{2}$ ] treatments. For any given panel, letters indicate significant differences within a given nonstructural carbohydrate form (Tukey's honestly significant difference at $P<0.05$ ). Bold, black vertical lines indicate the start of treatment. 


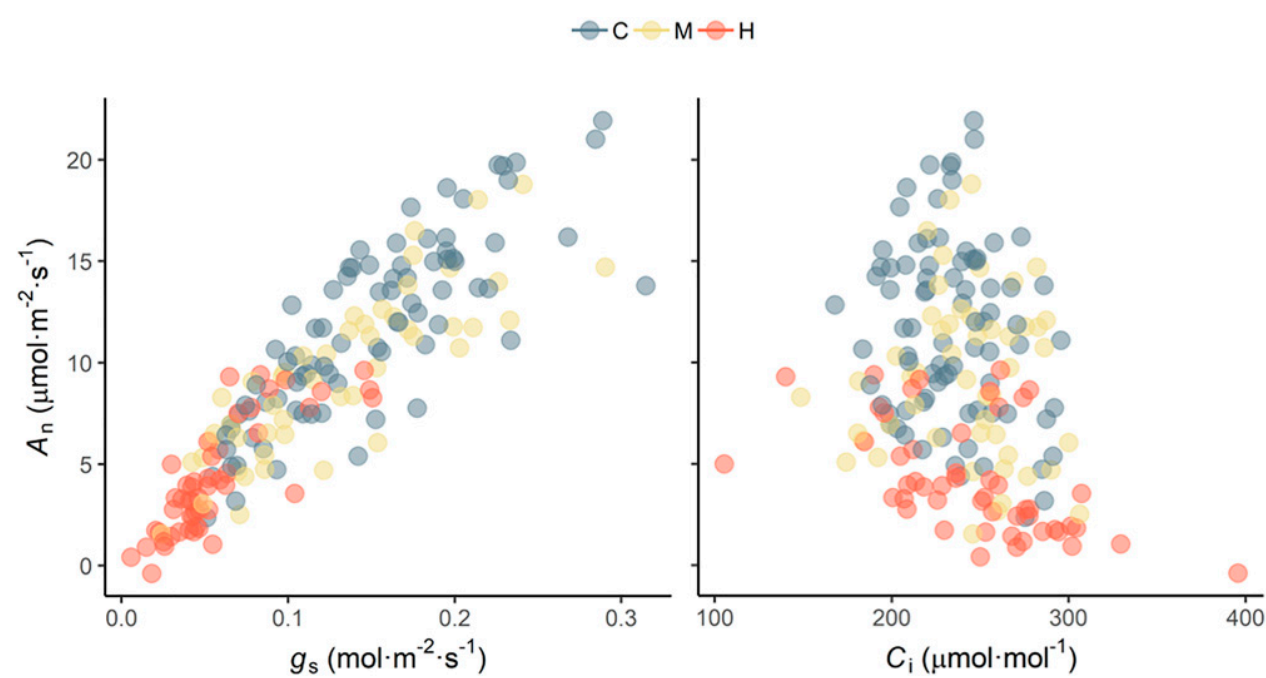

Fig. 4. Responses of photosynthesis $\left(A_{\mathrm{n}}\right)$ to stomatal conductance $\left(g_{\mathrm{S}}\right)$, and intercellular $\mathrm{CO}_{2}$ concentration $\left(C_{\mathrm{i}}\right)$ in Pis tacia atlantica $\times P$. integerrima 'UCB-1' after $\approx 100 \mathrm{~d}$ of control $[(\mathrm{C})$ modified Hoagland's solution $+0 \mathrm{~mm}$ $\mathrm{NaCl}$, moderate-salinity [(M) $\mathrm{C}+50 \mathrm{~mm} \mathrm{NaCl}+10 \mathrm{mM} \mathrm{CaCl}_{2}$, or high-salinity $[(\mathrm{H}) \mathrm{C}+100 \mathrm{~mm} \mathrm{NaCl}+20$ $\mathrm{mm} \mathrm{CaCl}_{2}$ ] treatments.

If demands for NSCs exceed the storage supply in contiguous periods of limited $A_{\mathrm{n}}$, the consequence may be just a postponement of mortality, not an avoidance. This is certainly the story emerging for drought's relationship with tree mortality (Adams et al., 2009; Choat et al., 2018; DesprezLoustau et al., 2006), and drought stress shares many physiological responses with salinity (Munns, 2002). Extreme depletions of reserves may be particularly challenging for deciduous species or cultivars such as the studied pistachio, which must regrow photosynthetic organs after periods of dormancy with whatever remains of their reserves (Tixier et al., 2019). All species in Pistacia have the additional challenge of generating not only the current year's leaves, but also preformed buds for the next year's crop with these reserves (Stevenson and Shackel, 1998). Although all our saplings lived through salinity treat-
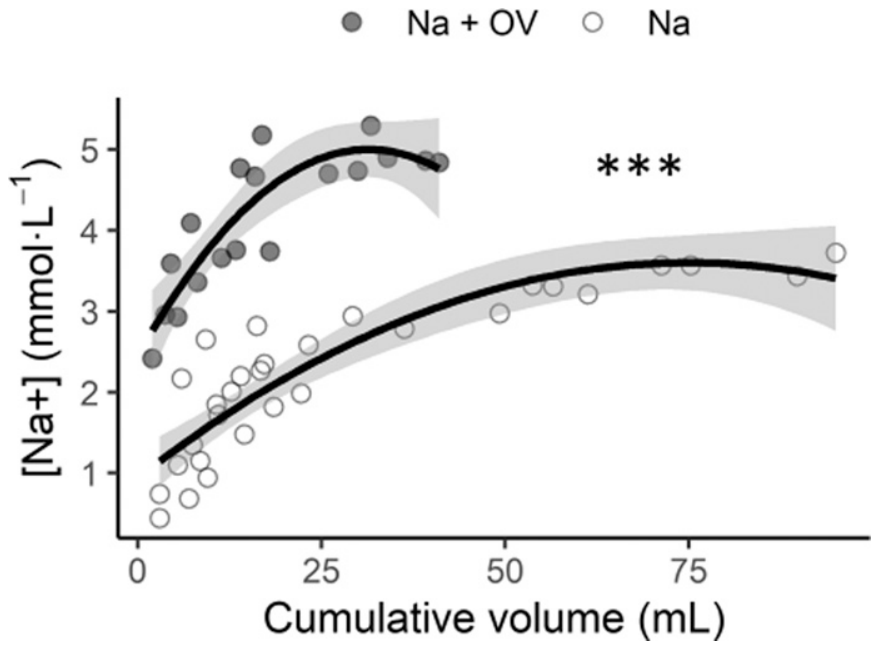

Fig. 5. Linear models of sodium ion $\left(\mathrm{Na}^{+}\right)$concentration and cumulative volumes exiting perfused branches of Pistacia atlantica $\times P$. integerri$m a$ 'UCB-1' when perfusion solutions were either just sodium chloride $\left[(\mathrm{Na}) \approx 4.35 \mathrm{~mm} \mathrm{Na}^{+}\right.$; open circles $\left.)\right]$or sodium chloride + sodium orthovanadate $\left[(\mathrm{NaOV}) \approx 4.85 \mathrm{mM} \mathrm{Na}^{+}\right.$; closed circles $\left.)\right]$. ***Significant differences between models $(P<0.001)$.

hypothesis, xylem retrieval of $\mathrm{Na}^{+}$does not appear to compete with NSCs for storage in the xylem tissues where it is used. Furthermore, any carbon costs derived from the active components of this process (Fig. 5) may be offset by the gains of maintaining sugar homeostasis without the degradation of starch as long as salinity is low enough for retrieval, effectively, to protect young tissues where salts are potentially more toxic. Like some of the world's most productive halophytes, the studied pistachio is able to include many of the salts in solution to its benefit; but, unlike a true halophyte, it must exclude these salts from young tissues, unable to use them for turgor maintenance or growth (Yeo and Flowers, 1980), and it is in these tissues that we observe starch degradation. ments, and many were able to recover any NSC deficit by the same time the following year, several died before or during leafout the following season ( $n=2$ and $n=4$ of 12 in moderate- and high-salinity treatments, respectively). We attribute sapling deaths to the additive strains of salinity stress, dormancy, and emergence from dormancy.

In conclusion, we address the relevance of our findings to horticultural practice. A tree's most distal or external parts are inherently (bark) or efficiently [fine roots (Hertel et al., 2013)] replaceable, and sacrificing these young tissues to concentrate and maintain NSCs in a tree's core may be a viable, although not infinitely exploitable, salt tolerance strategy. However, the sacrifice of distal parts is not a viable strategy for maintaining yields. Neither, perhaps, is an orchard-monitoring strategy that measures only total NSCs. Responding to any seasonally uncharacteristic spike in sugars or decrease in starch within growing tissues, before total NSC reserves are affected, may be the best practice for using carbohydrate measurements to manage pistachio orchards using saline irrigation. Last, this was a study of young, unbudded rootstocks in containers. Mature orchards of budded trees might fare much better than these relatively low-mass specimens, not in the least because larger trees are likely to have greater NSC reserves from which to draw.

\section{Literature Cited}

Adams, H.D., M. Guardiola-Claramonte, G. Barron-Gafford, J.C. Villegas, D.D. Breshears, C.B. Zou, P.A. Troch, and T.E. Huxman. 2009. Temperature sensitivity of drought-induced tree mortality portends increased regional die-off under global-change-type drought. Proc. Natl. Acad. Sci. USA 106:7063-7066, doi: 10.1073/pnas. 0901438106.

Amtmann, A. and M.J. Beilby. 2010. The role of ion channels in plant salt tolerance, p. 23-46. In: V. Demidchick and F. Maathius (eds.). Ion channels and plant stress responses: Signaling communication in plants. Springer, Berlin, Germany, doi: 10.1007/9783-642-10494-7_2. 
Arbona, V., A.J. Marco, D.J. Iglesias, M.F. López-Clement, M. Talon, and A. Gómez-Cadenas. 2005. Carbohydrate depletion in roots and leaves of salt-stressed potted Citrus clementina L. Plant Growth Regulat. 46:153-160, doi: 10.1007/s10725-005-7769-z.

Aubry, E., S. Dinant, F. Vilaine, C. Bellini, and R. le Hir. 2019. Lateral transport of organic and inorganic solutes. Plants 8:1-25, doi: 10.3390/plants8010020.

Choat, B., T.J. Brodribb, C.R. Brodersen, R.A. Duursma, R. López, and B.E. Medlyn. 2018. Triggers of tree mortality under drought. Nature 558:531-539, doi: 10.1038/s41586-018-0240-x.

Desprez-Loustau, M.-L., B. Marçais, L.-M. Nageleisen, D. Piou, and A. Vannini. 2006. Interactive effects of drought and pathogens in forest trees. Ann. For. Sci. 63:597-612, doi: 10.1051/forest:2006040.

Downton, W.J.S., B.R. Loveys, and W.J.R. Grant. 1990. Salinity effects on the stomatal behavior of grapevine. New Phytol. 116: 499-503, doi: 10.1111/j.1469-8137.1990.tb00535.x.

Drennan, P. and N.W. Pammenter. 1982. Physiology of salt excretion in the mangrove Avicennia marina (Forsk.). Vierh. New Phytol. 91: 597-606, doi: 10.1111/j.1469-8137.1982.tb03338.x.

Ferguson, L., V. Polito, and C. Kallsen. 2005. Managing salinity, soil, and water amendments, p. 129-146. In: L. Ferguson, R.H. Beede, M.W. Freeman, D.R. Haviland, B.A. Holtz, and C.E. Kallsen (eds.). Pistachio production manual. 4th ed. Fruit \& Nut Research and Information Center, University of California, Davis, CA.

Ferguson, L., J.A. Poss, S.R. Grattan, C.M. Grieve, D. Wang, C. Wilson, T.J. Donovan, and C.T. Chao. 2002. Pistachio rootstocks influence scion growth and ion relations under salinity and boron stress. J. Amer. Soc. Hort. Sci. 127:194-199, doi: 10.21273/JASHS.127.2.194.

Furze, M.E., B.A. Huggett, D.M. Aubrecht, C.D. Stolz, M.S. Carbone, and A.D. Richardson. 2019. Whole-tree nonstructural carbohydrate storage and seasonal dynamics in five temperate species. New Phytol. 221:1466-1477, doi: 10.1111/nph.15462.

García-Caparrós, P., A. Llanderal, M. Pestana, P.J. Correia, and M.T. Lao. 2016. Tolerance mechanisms of three potted ornamental plants grown under moderate salinity. Scientia Hort. 201:84-91, doi: 10.10 16/j.scienta.2016.01.031.

Godfrey, J., L. Ferguson, B.L. Sanden, A. Tixier, O. Sperling, S.R. Grattan, and M.A. Zwieniecki. 2019. Sodium interception by xylem parenchyma and chloride recirculation in phloem may augment exclusion in the salt tolerant Pistacia genus: Context for salinity studies on tree crops. Tree Physiol. 29:1484-1498, doi: 10.1093/treephys/ tpz054.

Granot, D., G. Kelly, O. Stein, and R. David-Schwartz. 2013. Substantial roles of hexokinase and fructokinase in the effects of sugars on plant physiology and development. J. Expt. Bot. 65:809-819, doi: $10.1093 / \mathrm{jxb} / \mathrm{ert} 400$.

Grieve, C.M., S.R. Grattan, and E.V. Maas. 2012. Plant salt tolerance, p. 405-459. In: W.W. Wallender and K.K. Tanji (eds.). Agricultural salinity assessment and management. 2nd ed. American Society of Civil Engineers, Reston, VA.

Hassine, A.B. and S. Lutts. 2010. Differential responses of saltbush Atriplex halimus L. exposed to salinity and water stress in relation to senescing hormones abscisic acid and ethylene. J. Plant Physiol. 167:1448-1456, doi: 10.1016/j.jplph.2010.05.017.

Hertel, D., T. Strecker, H. Müller-Haubold, and C. Leuschner. 2013. Fine root biomass and dynamics in beech forests across a precipitation gradient: Is optimal resource partitioning theory applicable to water-limited mature trees? J. Ecol. 101:1183-1200, doi: 10.1111/ 1365-2745.12124.

Hoffman, G.J., P.B. Catlin, R.M. Mead, R.S. Johnson, L.E. Francois, and D. Goldhamer. 1989. Yield and foliar injury responses of mature plum trees to salinity. Irr. Sci. 10:215-229, doi: $10.1007 /$ BF00 257954.

Horie, T., F. Hauser, and J.I. Schroeder. 2009. HKT transporter-mediated salinity resistance mechanisms in arabidopsis and monocot crop plants. Trends Plant Sci. 14:660-668, doi: 10.1016/j.tplants. 2009.08.009.
Kozlowski, T.T. and S.G. Pallardy. 2002. Acclimation and adaptive responses of woody plants to environmental stresses. Bot. Rev. 68:270334, doi: 10.1663/0006-8101(2002)068[0270:AAAROW]2.0.CO;2.

Leyva, A., A. Quintana, M. Sánchez, E.N. Rodriguez, J. Cremata, and J.C. Sánchez. 2008. Rapid and sensitive anthrone-sulfuric acid assay in microplate format to quantify carbohydrate in biopharmaceutical products: Method development and validation. Biologicals 36:134-141, doi: 10.1016/j.biologicals.2007.09.001.

Malagoli, P., D.T. Britto, L.M. Schulze, and H.J. Kronzucker. 2008. Futile $\mathrm{Na}+$ cycling at the root plasma membrane in rice (Oryza sativa L.): Kinetics, energetics, and relationship to salinity tolerance. J. Expt. Bot. 59:4109-4117, doi: 10.1093/jxb/ern249.

Marino, G., D. Zaccaria, R.L. Snyder, O. Lagos, B.D. Lampinen, L. Ferguson, S.R. Grattan, C. Little, K. Shapiro, M.L. Maskey, D.L. Corwin, E. Scudiero, and B.L. Sanden. 2019. Actual evapotranspiration and tree performance of mature micro-irrigated pistachio orchards grown on saline-sodic soils in the San Joaquin Valley of California. Agriculture 9: 76, doi: 10.3390/agriculture9040076.

McDowell, N.G. 2011. Mechanisms linking drought, hydraulics, carbon metabolism, and vegetation mortality. Plant Physiol. 155: 1051-1059, doi: 10.1104/pp.110.170704.

Munns, R. 2002. Comparative physiology of salt and water stress. Plant Cell Environ. 25:239-250, doi: 10.1046/j.0016-8025.2001.00808.x.

Munns, R. and M. Gilliham. 2015. Salinity tolerance of crops: What is the cost? New Phytol. 208:668-673, doi: 10.1111/nph.13519.

Munns, R., D.A. Day, W. Fricke, M. Watt, B. Arsova, B.J. Barkla, J. Bose, C.S. Byrt, Z.-H. Chen, K.J. Foster, M. Gilliham, S.W. Henderson, C.L.D. Jenkins, H.J. Kronzucker, S.J. Miklavcic, D. Plett, S.J. Roy, S. Shabala, M.C. Sheldon, K.L. Soole, N.L. Taylor, M. Tester, S. Wege, L.H. Wegner, and S.D. Tyerman. 2020a. Energy costs of salt tolerance in crop plants. New Phytol. 225: 1072-1090, doi: 10.1111/nph. 15864 .

Munns, R., R.A. James, and A. Laüchli. 2006. Approaches to increasing the salt tolerance of wheat and other cereals. J. Expt. Bot. 57: $1024-1043$.

Munns, R., J.B. Passioura, T.D. Colmer, and C.S. Byrt. 2020b. Osmotic adjustment and energy limitations to plant growth in saline soil. New Phytol. 225:1091-1096, doi: 10.1111/nph.15862.

Percival, G.C. 2005. Identification of foliar salt tolerance of woody perennials using chlorophyll fluorescence. HortScience 40:1892-1897, doi: 10.21273/HORTSCI.40.6.1892.

Perica, S., S. Goreta, and G.V. Selak. 2008. Growth, biomass allocation and leaf ion concentration of seven olive (Olea europaea L.) cultivars under increased salinity. Scientia Hort. 117:123-129, doi: 10.10 16/j.scienta.2008.03.020.

Rahneshan, Z., F. Nasibi, and A.A. Moghadam. 2018. Effects of salinity stress on some growth, physiological, biochemical parameters and nutrients in two pistachio (Pistacia vera L.) rootstocks. Plant-Environ. Interaction 13:73-82, doi: 10.1080/17429145.2018.1424355.

Raven, J.A. 1985. Regulation of $\mathrm{pH}$ and generation of osmolarity in vascular plants: A cost-benefit analysis in relation to efficiency of use of energy, nitrogen and water. New Phytol. 101:25-77, doi: 10. 1111/j.1469-8137.1985.tb02816.x.

Rook, F., S.A. Hadingham, Y. Li, and M.W. Bevan. 2006. Sugar and ABA response pathways and the control of gene expression. Plant Cell Environ. 29:426-434, doi: 10.1111/j.1365-3040.2005.01477.x.

Sala, A., F. Piper, and G. Hoch. 2010. Physiological mechanisms of drought-induced tree mortality are far from being resolved. New Phytol. 186:1136-1155, doi: 10.1111/j.1469-8137.2009.03167.x.

Sanden, B.L., L. Ferguson, H.C. Reyes, and S.R. Grattan. 2004. Effect of salinity on evapotranspiration and yield of San Joaquin Valley pistachios. Acta Hort. 664:583-589, doi: 10.17660/ActaHortic.2004.664.73.

Schiestl-Aalto, P., K. Ryhti, A. Mäkela, M. Peltoniemi, J. Bäck, and L. Kulmala. 2019. Analysis of the NSC storage dynamics in tree organs reveals the allocation to belowground symbionts in the framework of whole tree carbon balance. Front. For. Glob. Change 2:17, doi: 10.3389/ffgc.2019.00017. 
Schneider, C.A., W.S. Rasband, and K.W. Eliceiri. 2012. NIH Image to ImageJ: 25 Years of image analysis. Nat. Methods 9:671-675, doi: 10.1038/nmeth.2089.

Scholander, P.F., E.D. Bradstreet, E.A. Hemmingsen, and H.T. Hammel. 1965. Sap pressure in vascular plants. Science 148:339-346, doi: 10. 1126/science.148.3668.339.

Scholander, P.F., H.T. Hammel, E. Hemmingsen, and W. Garey. 1962. Salt balance in mangroves. Plant Physiol. 37:722-729, doi: 10. 1104/pp.37.6.722.

Slama I., T. Ghnaya, A. Savouré, and C. Abdelly. 2008. Combined effects of long-term salinity and soil drying on growth, water relations, nutrient status and proline accumulation of Sesuvium portulacastrum. C. R. Biol. 331:442-451, doi: 10.1016/j.crvi.2008.03.006.

Sperling, O., T. Kamai, A. Tixier, A. Davidson, K. Jarvis-Shean, E. Raveh, T.M. Dejong, and M.A. Zwieniecki. 2019. Predicting bloom dates by temperature-mediated kinetics of carbohydrate metabolism in deciduous trees. Agr. For. Meteorol. 276:107643, doi: 10.1016/ j.agrformet.2019.107643.

Stevenson, M.T. and K.A. Shackel. 1998. Alternate bearing in pistachio as a masting phenomenon: Construction cost of reproduction versus vegetative growth and storage. J. Amer. Soc. Hort. Sci. 123: 1069-1075, doi: 10.21273/JASHS.123.6.1069.

Sun, J., S. Chen, S. Dai, R. Wang, N. Li, X. Shen, X. Zhou, C. Lu, X. Zheng, Z. Hu, Z. Zhang, J. Song, and Y. Xue. 2009. NaCl-induced alterations of cellular and tissue ion fluxes in roots of salt-resistant and salt-sensitive poplar species. Plant Physiol. 149:1141-1153, doi: $10.1104 / p p .108 .129494$

Thalmann, M. and D. Santelia. 2017. Starch as a determinant of plant fitness under abiotic stress. New Phytol. 214:943-951, doi: 10.1111/ nph.14491.

Tixier, A., G.A. Gambetta, J. Godfrey, J. Orozco, and M.A. Zwieniecki. 2019. Non-structural carbohydrates in woody perennials: The tale of winter survival and spring arrival. Front. For. Glob. Change. 2:1-8, doi: $10.3389 /$ ffgc. 2019.00018 .

Tixier, A., J. Orozco, A. Amico-Roxas, J.M. Earles, and M.A. Zwieniecki. 2018. Diurnal variation in nonstructural carbohydrate storage in trees: Remobilization and vertical mixing. Plant Physiol. 178:1602-1613, doi: 10.1104/pp.18.00923.

Tixier, A., O. Sperling, J. Orozco, B. Lampinen, A. Amico-Roxas, S. Saa, J.M. Earles, and M.A. Zwieniecki. 2017. Spring bud growth depends on sugar delivery by xylem and water recirculation by phloem Münch flow in Juglans regia. Planta 246:495-508, doi: 10.1007/ s00425-017-2707-7.

Tyerman, S.D., R. Munns, W. Fricke, B. Arsova, B.J. Barkla, J. Bose, H. Bramley, C. Byrt, Z. Chen, T.D. Colmer, T. Cuin, D.A. Day, K.J. Foster, M. Gilliham, S.W. Henderson, T. Horie, C.L.D. Jenkins, B.N. Kaiser, M. Katsuhara, D. Plett, S.J. Miklavcic, S.J. Roy, F. Rubio, S. Shabala, M. Shelden, K. Soole, N.L. Taylor, M. Tester, M. Watt, S. Wege, L.H. Wegner, and Z. Wen. 2019. Energy costs of salinity tolerance in crop plants. New Phytol. 221:25-29, doi: 10.1111/ nph. 15555 .

van Bel, A.J.E. 1990. Xylem-phloem exchange via the rays: The undervalued route of transport. J. Expt. Bot. 41:631-644, doi: 10.1093/jxb/ 41.6.631.

Vijayan, K. 2009. Approaches for enhancing salt tolerance in mulberry. Plant Omics 2:41-49.

Walker, R.R., E. Törökfalvy, and M.H. Behboudian. 1988. Photosynthetic rates and solute partitioning in relation to growth of salt-treated pistachio plants. Aust. J. Plant Physiol. 15:787-798.

Yeo, A.R. 1983. Salinity resistance: Physiologies and prices. Physiol. Plant. 58:214-222, doi: 10.1111/j.1399-3054.1983.tb04172.x.

Yeo, A.R. and T.J. Flowers. 1980. Salt tolerance in the halophyte Suaeda maritima L. Dum. Intracellular compartmentation of ions. J. Expt. Bot. 32:487-497.

Zimmerman, U., H.-J. Wagner, M. Heidecker, S. Mimietz, H. Schneider, M. Szimtenings, A. Haase, R. Mitlöhner, W. Kruck, R. Hoffman, and W. König. 2002. Implications of mucilage on pressure bomb measurements and water lifting in trees rooting in high-salinity water. Trees 16:100-111, doi: 10.1007/s00468-001-0135-5.

Zwieniecki, M.A., P.J. Melcher, and M. Holbrook. 2001. Hydrogel control of xylem hydraulic conductance in plants. Science 291:1059-1062, doi: 10.1126/science.1057175. 